\title{
CRBN Gene
}

National Cancer Institute

\section{Source}

National Cancer Institute. CRBN Gene. NCI Thesaurus. Code C104140.

This gene plays a role in limb outgrowth and may play a role in brain development. 